\title{
Staphylococcus aureus and Escherichia coli Cause Deviating Expression Profiles of Cytokines and Lactoferrin Messenger Ribonucleic Acid in Mammary Epithelial Cells
}

\author{
B. Griesbeck-Zilch, ${ }^{*}$ H. H. D. Meyer, ${ }^{*}$ Ch. Kühn, $\dagger$ M. Schwerin, $\dagger$ and O. Wellnitz ${ }^{1}$ \\ *Physiology Weihenstephan, Technical University Munich, D-85350 Freising, Germany \\ †Research Institute for the Biology of Farm Animals, D-18196 Dummerstorf, Germany \\ $\ddagger$ Veterinary Physiology, Vetsuisse Faculty, University of Bern, $\mathrm{CH}-1725$ Posieux, Switzerland
}

\begin{abstract}
Pathogens invading the mammary gland cause a complex signaling network that activates the early immune defense and leads to an outcome of inflammation symptoms. To examine the importance of mammary epithelial cells in these regulations and interactions resulting in a pathogen-related course of mastitis, we characterized the mRNA expression profile of key molecules of the innate immune system by quantitative realtime PCR. Mammary gland epithelial cells isolated on d 42 of lactation from 28 first-lactation Holstein dairy cows were cultured separately under standardized conditions and treated for 1,6 , and $24 \mathrm{~h}$ with heat-inactivated gram-positive (Staphylococcus aureus) and gramnegative (Escherichia coli) bacteria. Both pathogens increased mRNA expression patterns of proteins involved in pathogen recognition such as Toll-like receptors and nuclear factor- $\kappa \mathrm{B}$, whereas gram-negatives acted as a stronger stimulus. Furthermore, this could be confirmed by the expression profile of the proinflammatory cytokines tumor necrosis factor alpha, IL-1 beta, IL-6, and chemokines such as IL-8 and RANTES (regulated upon activation, normal T-cell expressed and secreted). Remarkably, at a low level of mRNA expression after $1 \mathrm{~h}$ of treatment these cytokines and chemokines were expressed at a significantly higher level in Staphyloccocus aureus than in Escherichia coli affected cells. Lactoferrin showed a deviating expression pattern to pathogen stimulation (i.e., at the 1 -h measuring point Escherichia coli induced a higher mRNA expression, whereas the highest level was reached after $24 \mathrm{~h}$ of stimulation with Staphylococcus aureus). Complement factor 3 was the only measured factor that responded equally to both microorganisms. Our data emphasize the role of mammary epithelial cells in the immune
\end{abstract}

Received October 5, 2007.

Accepted February 6, 2008.

${ }^{1}$ Corresponding author: olga.wellnitz@physio.unibe.ch defense of the udder and confirm their contribution to pathogen-related different courses of mastitis.

Key words: mammary epithelial cell, cytokine, lactoferrin

\section{INTRODUCTION}

Mastitis, defined as an inflammation of the mammary gland, is estimated to be the most prevalent and most costly production disease in dairy herds of developed countries (Seegers et al., 2003). In most cases the inflammation is caused by invading pathogens that influence, in addition to environmental and cow factors, the clinical pattern. An infection with gram-positive bacteria such as Staphylococcus aureus can result in a chronic mastitis that persists lifelong (Sutra and Poutrel, 1994). Gram-negative microorganisms, however, especially Escherichia coli, can often be isolated from udders of animals suffering from a severe clinical mastitis (Hogan and Smith, 2003).

The last barrier that intramammary pathogens meet after overcoming the teat canal is presented by the epithelial cells covering the inner surface of the mammary gland. On the one hand, epithelial cells are part of the functional unit of the udder because they are responsible for synthesis of many milk components offering a perfect nutritional and immunological supply to the offspring (Korhonen et al., 2000; McManaman and Neville, 2003). On the other hand, these cells provide an important link between the outside environment and the body interior because they are able to recognize conserved molecular patterns of invading microorganisms via pattern recognition receptors, including Toll-like receptors (TLR; Rainard and Riollet, 2006). These receptors generate signals affecting activity of the immune system. Thirteen TLR have been identified in mammalian species, and the expression of 10 is known in cattle (Takeda et al., 2003; Menzies and Ingham, 2006).

The TLR2 is activated by peptidoglycan and lipoteichoic acid that are components of the cell membrane of 
Table 1. Sequences, accession numbers of the PCR primers, and length of the PCR products

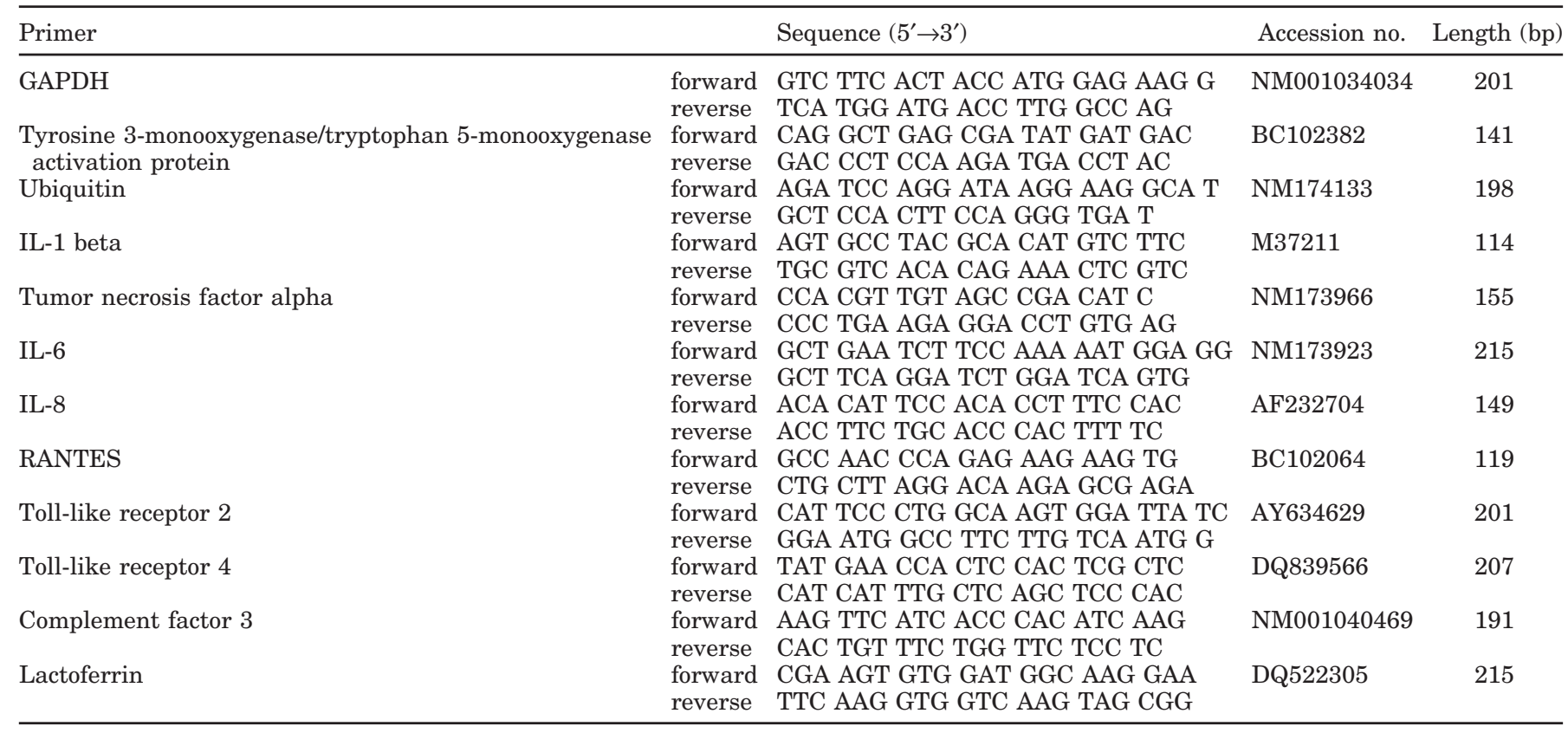

gram-positive bacteria, whereas gram-negative microorganisms are recognized by TLR4, where LPS acts as a ligand (Pandey and Agrawal, 2006). The activation of several signaling molecules leads to a release of transcription factors, like nuclear factor- $\kappa$ B $(\mathbf{N F} \kappa \mathbf{B})$ that translocates into the nucleus and regulates expression of cytokines and other mediators playing a crucial role in the immune defense, cell differentiation, and apoptosis. The $\mathrm{NF} \kappa \mathrm{B}$ family consists of the following 5 proteins: NF $\kappa \mathrm{B} 1$ (p105/p50), NF $\kappa \mathrm{B} 2$ (p100/p52), RelA (p65), RelB, and c-Rel. They form homo- and heterodimers in which RelA (p65) has been demonstrated to be of great importance for the antiapoptotic and proinflammatory properties of $\mathrm{NF} \kappa \mathrm{B}$ (Pahl, 1999; Liang et al., 2004). In numerous in vitro and in vivo studies, proinflammatory signals like tumor necrosis factor alpha (TNF $\boldsymbol{\alpha}$ ), IL-1 $\beta$, and IL-6 could be shown being involved in a deviating immune response to infection with S. aureus and E. coli (Riollet et al., 2000; Bannerman et al., 2004). Furthermore, chemokines such as IL-8 and RANTES (regulated upon activation, normal T-cell expressed and secreted, also known as CCL5) participate in the mastitis reaction by attraction of neutrophils to the site of inflammation (Boudjellab et al., 2000; Persson Waller et al., 2003; Pareek et al., 2005). The complement system and lactoferrin also belong to the innate pathogen defense mechanisms in the bovine mammary gland and the complement factor (C) 3 and lactoferrin are supposed to be synthesized by bovine mammary gland epithelial cells (bMEC) (Hagiwara et al., 2003; Pfaffl et al., 2003; Rainard, 2003; Schmitz et al., 2004; Wellnitz and Kerr, 2004). Beside its antimicrobial properties, lactoferrin was found to have an impact on regulation of proinflammatory cytokines (Berlutti et al., 2006). Expression of lactoferrin seems to be determined by hormonal influences, whereas some studies investigated its relation to bacterial infection directly (Teng, 1999, 2002; Zheng et al., 2005).

In the present investigation we wanted to explore the role of bovine mammary gland epithelial cells from a sufficient number of individuals in the complex network of interactions and regulations of immune defense and we examined its influence on pathogen-related differences in mastitis course. More knowledge about immunological reactions at the epithelial barrier could give evidence on how to interfere pathogen invasions by a therapeutical support of selected factors participating in the signaling pathway and could also be used for genetically assisted selection to improve udder health.

\section{MATERIALS AND METHODS}

\section{Primary Cell Culture of Mammary Epithelial Cells}

In 28 first lactating German Holstein dairy cows, udder health was controlled continuously by measuring SCC in milk samples and by clinical investigations. Milk samples of each quarter were tested for bacterial infection on slaughtering day. All animals were slaughtered on d 42 of lactation. Primary cell cultures from the mammary gland epithelial cells were obtained as described previously (Wellnitz and Kerr, 2004) with 

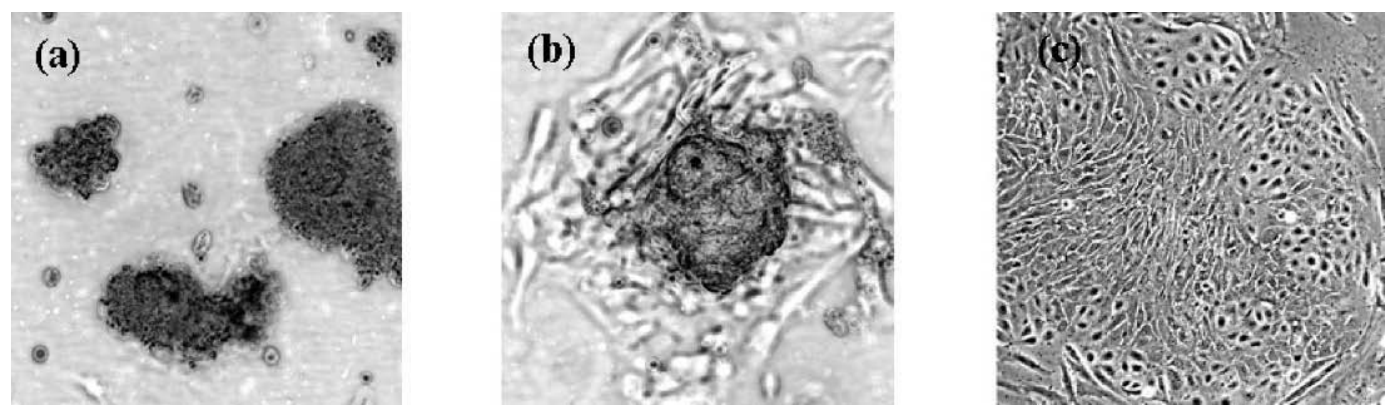

Figure 1. Bovine mammary gland epithelial cells in cell culture environment. On the first day isolated acini are already attached on the tissue flask surface (a). New epithelial cells are growing out of the acinus on the second day (b). Typical cobblestone-like conformation of epithelial cells on the fifth day of cultivation (c).

slight modifications. Immediately after killing, a deep sagittal section was made through one quarter of the udder and two pieces of the parenchyma of about $1.5 \times$ $1.5 \times 1.5 \mathrm{~cm}$ were taken as aseptically as possible. Samples were transported to the laboratory in $200 \mathrm{~mL}$ of room-temperature Hanks' balanced salt solution (HBSS; Sigma-Aldrich, Munich, Germany) containing $200 \mu \mathrm{g} / \mathrm{mL}$ of penicillin, $200 \mu \mathrm{g} / \mathrm{mL}$ of streptomycin, 200 $\mu \mathrm{g} / \mathrm{mL}$ of gentamicin, and $10 \mu \mathrm{g} / \mathrm{mL}$ of amphotericin B (Sigma-Aldrich). Tissue was minced and blood and milk residues were flushed away with HBSS. Samples were transferred to a digestion mix consisting of $200 \mathrm{~mL}$ of HBSS, $0.5 \mathrm{mg} / \mathrm{mL}$ of collagenase IA, $0.4 \mathrm{mg} / \mathrm{mL}$ of DNase type I, and $0.5 \mathrm{mg} / \mathrm{mL}$ of hyaluronidase (enzymes from Sigma-Aldrich) and the same antibiotics mentioned above and placed in a shaking incubator at $37^{\circ} \mathrm{C}$ for $165 \mathrm{~min}$. Cells were separated from connective tissue and nonepithelial cell conglomerates by filtration and centrifugation ( $500 \mathrm{U} ; 4 \mathrm{~min}$ ). The pellet was resuspended with HBSS and the procedure was repeated 2 times each with a strainer of a decreasing pore size (smallest one: $100 \mu \mathrm{m}, \mathrm{BD}$ Biosciences, Erembodegem, Belgium). Final pellet was resuspended in Dulbecco's modified Eagle's medium nutrient mixture F-12 Ham (DMEM/F12, Sigma-Aldrich) containing penicillin, streptomycin, gentamicin, and amphotericin B in the same concentrations as described above, $10 \% \mathrm{FBS}$ and $10 \mu \mathrm{L} / \mathrm{mL}$ of ITS $(0.5 \mathrm{mg} / \mathrm{mL}$ of bovine insulin, $0.5 \mathrm{mg} /$ $\mathrm{mL}$ of apo-transferrin, $0.5 \mu \mathrm{g} / \mathrm{mL}$ of sodium selenite; Sigma-Aldrich) and incubated in a $75-\mathrm{cm}^{2}$ tissue culture flask, (Greiner Bio-one, Frickenhausen, Germany) for $40 \mathrm{~min}$ at $37^{\circ} \mathrm{C}, 5 \% \mathrm{CO}_{2}$, and $90 \%$ humidity. In this time fibroblasts attached and epithelial cells could be isolated by decanting. Cells were seeded in $25-\mathrm{cm}^{2}$ tissue culture flasks (Greiner Bio-one) and cultured until they reached about $80 \%$ confluence. The typical growing behavior of mammary epithelial cells is illustrated in Figure 1. Then, cells were cryopreserved at $-80^{\circ} \mathrm{C}$ in 1 $\mathrm{mL}$ of freezing medium containing DMEM/F12, $20 \%$
FBS, and 10\% dimethyl sulfoxide (DMSO). To verify the epithelial origin of the cells, an immunocytochemical staining of cytoceratins characterizing this cell type was conducted randomly as described in Wellnitz and Kerr (2004). Aliquots of cryopreserved cells were cultured until confluence on collagen-coated glass cover slips in Petri dishes. For immunohistochemical staining monoclonal anticytoceratin peptide 18 (Sigma-Aldrich) was used according to manufacturer's protocol. The predominant cell type was represented by epithelial cells (approximately 90 to $95 \%$ ).

\section{Treatment of Epithelial Cells with Mastitis Pathogens}

One colony of $S$. aureus M60 (Bramley et al., 1989) and $E$. coli, isolated from a milk sample of bovine mastitis and verified with a standard protocol, were incubated over night in Luria-Bertani (E. coli) or tryptone soy broth ( $S$. aureus) medium at $37^{\circ} \mathrm{C}$ and diluted 1:1,000 with the respective medium on the next day. Bacteria were kept under cultivation conditions until an optical density of 0.1 to 0.25 at $600 \mathrm{~nm}$ was reached. For defining concentrations, the plate dilution method was used. Heat inactivation of the pathogens was conducted at $63^{\circ} \mathrm{C}$ for $30 \mathrm{~min}$. Inactivated bacteria cannot divide and this prevents bacterial overgrowth in the cell culture medium to assure a constant and, for both pathogens, comparable infection pressure over $24 \mathrm{~h}$. Inactivation efficiency was tested on blood agar plates. Epithelial cells were thawed and cultured in DMEM/ F12 medium containing $100 \mu \mathrm{g} / \mathrm{mL}$ of penicillin, 100 $\mu \mathrm{g} / \mathrm{mL}$ of streptomycin, $100 \mu \mathrm{g} / \mathrm{mL}$ of gentamicin, $5 \mu \mathrm{g} /$ $\mathrm{mL}$ of amphotericin, $10 \% \mathrm{FBS}$, and $10 \mu \mathrm{L} / \mathrm{mL}$ of ITS for 2 further passages and then seeded in 6-well tissue culture plates (Greiner Bio-one) at a concentration of 300,000 cells/well. On the following day medium was replaced by DMEM/F12 supplemented with ITS solely. On the second day after seeding at a confluence of about 
$70 \%$, this medium was refreshed and $100 \mu \mathrm{L}$ of bacterial solution representing a multiplicity of infection of 10 was added. Control cells were treated with $100 \mu \mathrm{L}$ of PBS only.

\section{Real-Time RT-PCR for mRNA Quantification}

After 1,6 , and $24 \mathrm{~h}$ cells were harvested and total RNA was extracted with the TriFast reagent (PeqLab, Erlangen, Germany) as described in manufacturer's instructions. For converting the RNA template in cDNA $1 \mu \mathrm{g}$ of RNA was reverse transcribed by $200 \mathrm{U}$ of MMLV reverse transcription RNase (H-; Promega, Mannheim, Germany) using $50 \mu M$ random primers (Invitrogen, Karlsruhe, Germany) and $10 \mathrm{~m} M$ dNTP (Fermentas, St. Leon-Rot, Germany) as established in the user's manual. A negative control was added without enzyme for excluding DNA contaminations in the RNA. To increase precision of pipetting procedure workstation epMotion 5075 (Eppendorf, Hamburg, Germany) was used. For the qPCR reaction $2 \mu \mathrm{L}$ of cDNA equivalent to $16.66 \mathrm{ng}$ of total RNA was amplified in a 15-mL reaction volume with the Mastercycler RealPlex (Eppendorf) using RealMasterMix (Eppendorf) and 7.5 $\mathrm{n} M$ reverse and forward primer each. Here, a further negative control was included by measuring one sample containing water instead of cDNA. New primers were designed with an online primer design software (MWG Biotech, Ebersberg, Germany) and synthesized by MWG Biotech (Table 1). The following protocol was used: denaturation $\left(95^{\circ} \mathrm{C}, 2 \mathrm{~min}\right)$, cycling program $\left[95^{\circ} \mathrm{C}\right.$ denaturation $(2 \mathrm{~s}) ; 60 / 62^{\circ} \mathrm{C}$ annealing, depending on primer $(10 \mathrm{~s}) ; 68^{\circ} \mathrm{C}$ elongation $\left.(2 \mathrm{~s})\right]$ and melting curve analysis. At the cycle number at which fluorescence signal intersected with the threshold, the $\mathrm{C}_{\mathrm{T}}$ (threshold cycle) value of a sample was set. Threshold was determined automatically by the CalQplex realplex software (Version 1.5; Eppendorf, Ebersberg, Germany) so that it was significantly above the noise of baseline. Predicted size of PCR products was tested by agarose gel electrophoresis after ethidium bromide staining.

\section{Data Analysis of Real-Time RT-PCR}

For the relative quantification of mRNA the $\mathrm{C}_{\mathrm{T}}$-values of the target genes were normalized against the arithmetic mean (AM) of 3 reference genes: GAPDH, ubiquitin, and tyrosine 3-monooxygenase/tryptophan5monooxygenase activation protein (YWHAZ).

$$
\Delta \mathrm{C}_{\mathrm{T}}=\mathrm{C}_{\mathrm{T} \text { (AM of housekeeping genes) }}-\mathrm{C}_{\mathrm{T} \text { (target gene) }} .
$$

Data are presented as $\Delta \Delta \mathrm{C}_{\mathrm{T}} \pm \mathrm{SEM}$ to show the effect of the different mastitis pathogens on immune response (Livak and Schmittgen, 2001).

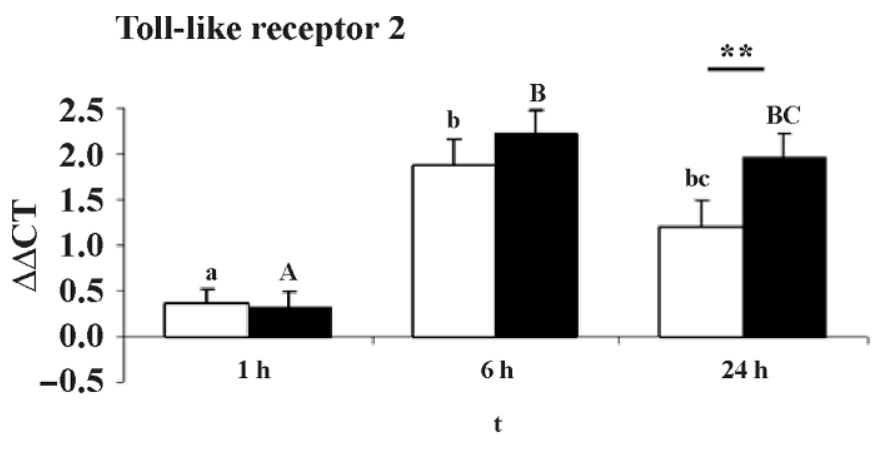

Toll-like receptor 4

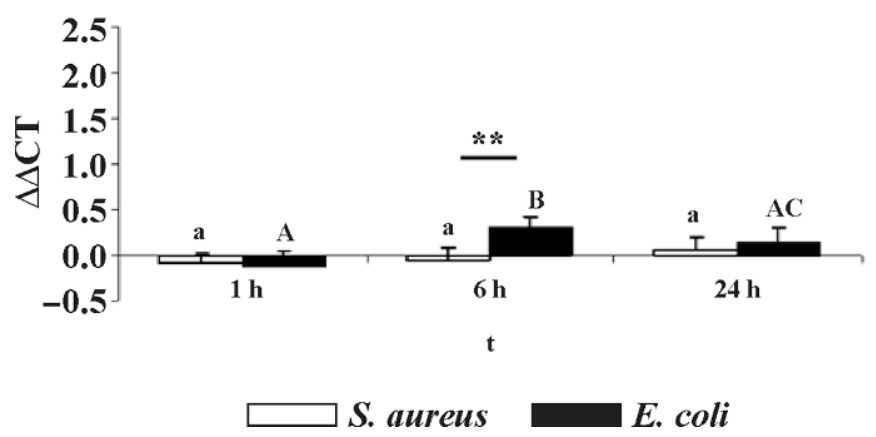

Figure 2. Pathogen recognition: mRNA expression $(\Delta \Delta \mathrm{CT})$ of Tolllike receptor 2 and Toll-like receptor 4 of 28 cows after treatment with Escherichia coli and Staphylococcus aureus for 1, 6, and $24 \mathrm{~h}$ (t). Data are presented as means \pm SEM. ${ }^{\mathrm{a}-\mathrm{c}}$ Means without common letters within the $S$. aureus-treated group differ significantly at the measured time points $(P<0.05)$. ${ }^{\mathrm{A}-\mathrm{C}}$ Means without common letters within the $E$. coli-treated group differ significantly at the measured time points $(P<0.05)$. Significant differences between $E$. coli- and $S$. aureus-treated cells within one time point are indicated by ** $(P$ $<0.01)$.

$$
\Delta \Delta \mathrm{C}_{\mathrm{T}}=\Delta \mathrm{C}_{\mathrm{T} \text { (control) }}-\Delta \mathrm{C}_{\mathrm{T} \text { (treatment) }}
$$

Statistical analysis was conducted with the SigmaStat v. 3.00 software (SPSS Inc., Chicago, IL). Means were compared by paired $t$-test or one-way repeated measured ANOVA. Results were considered as statistically significant at $P<0.05$.

\section{RESULTS}

\section{Expression of Toll-Like Receptors and RelA}

The mRNA expression data for TLR2, TLR4, and RelA are shown in Figures 2 and 3. Staphylococcus aureus and $E$. coli both caused an increased level of expression of TLR2. The mRNA level increased significantly after $6 \mathrm{~h}$ in both groups, and no crucial changes could be detected after $24 \mathrm{~h}$. Differences between the $E$. coli and the $S$. aureus treated groups could be ob- 
RelA

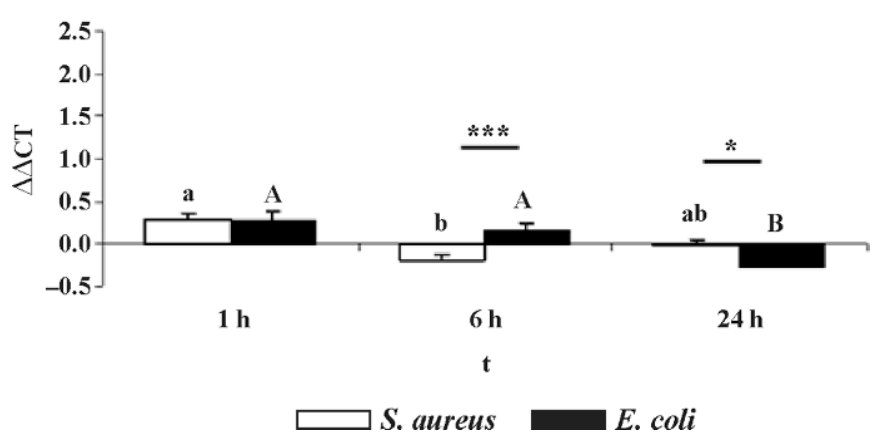

Figure 3. Signal transmission: mRNA expression $(\Delta \Delta \mathrm{CT})$ of RelA, a subunit of nuclear factor- $\kappa \mathrm{B}$, of 28 cows after treatment with Escherichia coli and Staphylococcus aureus for 1, 6, and $24 \mathrm{~h}(\mathrm{t})$. Data are presented as means \pm SEM. ${ }^{\mathrm{a}, \mathrm{b}}$ Means without common letters within the $S$. aureus-treated group differ significantly at the measured time points $(P<0.05)$. ${ }^{\mathrm{A}, \mathrm{B}}$ Means without common letters within the $E$. coli-treated group differ significantly at the measured time points $(P$ $<0.05)$. Significant differences between $E$. coli- and $S$. aureus-treated cells within one time point are indicated by $*(P<0.05)$ and $* * *(P$ $<0.001)$.

served only after $24 \mathrm{~h}$, when $S$. aureus-induced expression was significantly lower.

The TLR4 mRNA showed a significant increase only in the $E$. coli-treated group after $1 \mathrm{~h}$. At that time expression in $S$. aureus-treated cells were significantly lower.

The mRNA level of RelA decreased in both groups in the observed period and expression was reduced significantly earlier in S. aureus-affected epithelial cells.

\section{Expression of Cytokines, Chemokines, Lactoferrin, and $\mathrm{C} 3$}

The expression of TNF $\alpha$ mRNA increased significantly in both $S$. aureus and $E$. coli treated cells after 1 h. Staphylococcus aureus induced a significantly higher expression level after $1 \mathrm{~h}$, but after 6 and $24 \mathrm{~h}$ transcription activity in $E$. coli-treated cells was higher. The same profile was shown by IL- $1 \beta$ expression (Figure 4 ).

The IL-6 mRNA expression showed the same course as $\mathrm{TNF} \alpha$ and IL- $1 \beta$ in both treatments, but no differences in the 2 groups could be detected after $24 \mathrm{~h}$. Staphylococcus aureus-affected cells showed no significant changes in expression of IL-8 in the measured period. In contrast, $E$. coli induced a significant increase after $1 \mathrm{~h}$. The RANTES increased in the $S$. aureus and in the $E$. coli group after $1 \mathrm{~h}$ significantly, whereas after 6 and $24 \mathrm{~h}$ expression was significantly higher in $E$. coli-treated cells (Figure 4).

Transcription activity of lactoferrin was not elevated significantly until $24 \mathrm{~h}$ in both treatments. Significant
Iumor necrosis factor alpha
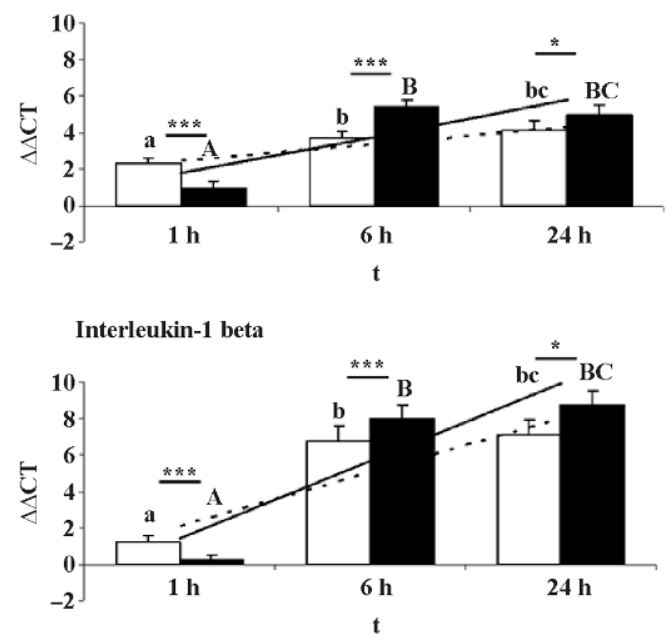

Interleukin-6

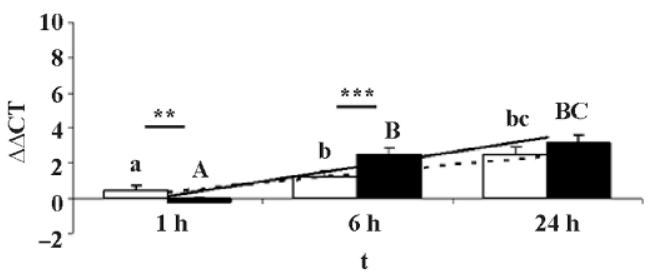

Interleukin-8

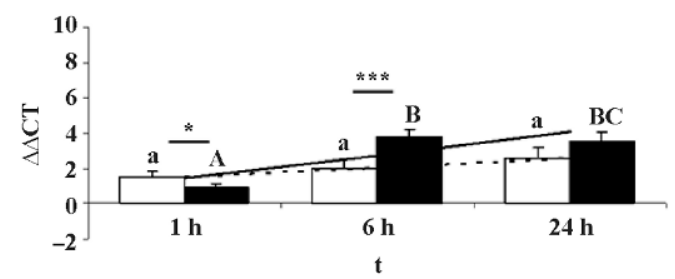

RAN'TES

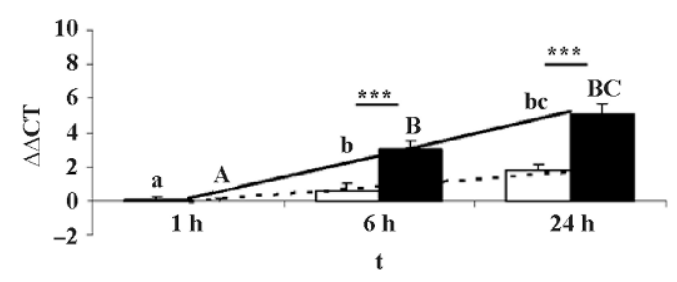

$\square$ S. aureus $\square$ E. coli $\longrightarrow$ Linear (E. coli) ---Linear (S. aureus)

Figure 4. Signaling pattern: mRNA expression $(\Delta \Delta \mathrm{CT})$ of tumor necrosis factor alpha, IL-1 beta, IL-6, IL-8, and RANTES of 28 cows after treatment with Escherichia coli and Staphylococcus aureus for 1,6 , and $24 \mathrm{~h}(\mathrm{t})$. Data are presented as means $\pm \mathrm{SEM}$; a trendline is shown to emphasize the deviating expression profile between $E$. coli and $S$. aureus. ${ }^{\text {a-c }}$ Means without common letters within the $S$. aureus-treated group differ significantly at the measured time points $(P<0.05) .{ }^{\mathrm{A}-\mathrm{C}}$ Means without common letters within the $E$. coli-treated group differ significantly at the measured time points $(P<0.05)$. Significant differences between $E$. coli- and $S$. aureus-treated cells within one time point are indicated by $*(P<0.05), * *(P<0.01)$, and *** $(P<0.001)$. 


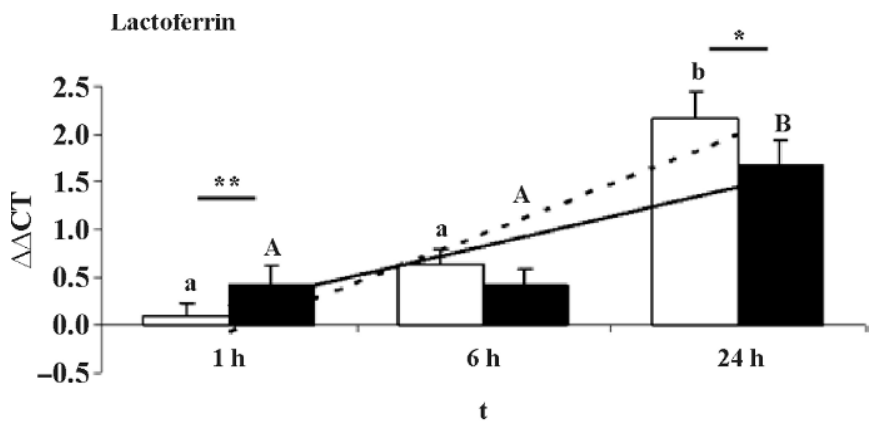

$\square S$. aureus $\square$ E. coli - Linear $($ E. coli) ---Linear (S. aureus)

Figure 5. Lactoferrin: mRNA expression $(\Delta \Delta \mathrm{CT})$ of lactoferrin of 28 cows after treatment with Escherichia coli and Staphylococcus aureus for 1,6 , and $24 \mathrm{~h}(\mathrm{t})$. Data are presented as means $\pm \mathrm{SEM}$; a trendline is shown to emphasize the deviating expression profile between $E$. coli and $S$. aureus. ${ }^{\mathrm{a}, \mathrm{b}}$ Means without common letters within the $S$. aureus-treated group differ significantly at the measured time points $(P<0.05)$. ${ }^{\mathrm{A}, \mathrm{B}}$ Means without common letters within the $E$. coli-treated group differ significantly at the measured time points $(P<0.05)$. Significant differences between $E$. coli- and $S$. aureus-treated cells within one time point are indicated by $*(P<$ $0.05)$ and $* *(P<0.01)$.

differences between $E$. coli and $S$. aureus could be shown after 1 and 24 but not after $1 \mathrm{~h}$. After $1 \mathrm{~h}$ expression was elevated significantly in $E$. coli-affected cells, but after $24 \mathrm{~h}$ in $S$. aureus-treated samples also (Figure 5).

The C3 transcription profile was the same in both treatments with a significant increase of expression over the whole period (Figure 6).

\section{DISCUSSION}

Our experiment demonstrates a pathogen-related response in mRNA expression of pathogen-recognition factors, proinflammatory cytokines, chemokines, and lactoferrin by mammary gland epithelial cells.

The cell culture model based on a large number $(\mathrm{n}=$ 28 ) and homogeneous group of animals slaughtered on d 42 of their first lactation is particularly suitable for reducing animal-dependent effects because it is well examined that the course of mastitis is influenced [e.g., by the number and stage of lactation and former infections (Burvenich et al., 2003; Hogan and Smith, 2003; Barkema et al., 2006)]. Epithelial cells building the inner surface of the mammary gland separate the host from its environment. Several studies showed epithelial cells in the mammary gland being actively involved in immune defense by sending signals or by producing antimicrobial molecules (Goldammer et al., 2004; Wellnitz and Kerr, 2004; Strandberg et al., 2005; Lahouassa et al., 2007). Obviously, primary cell culture is the best tool for characterizing epithelial cells in the mammary

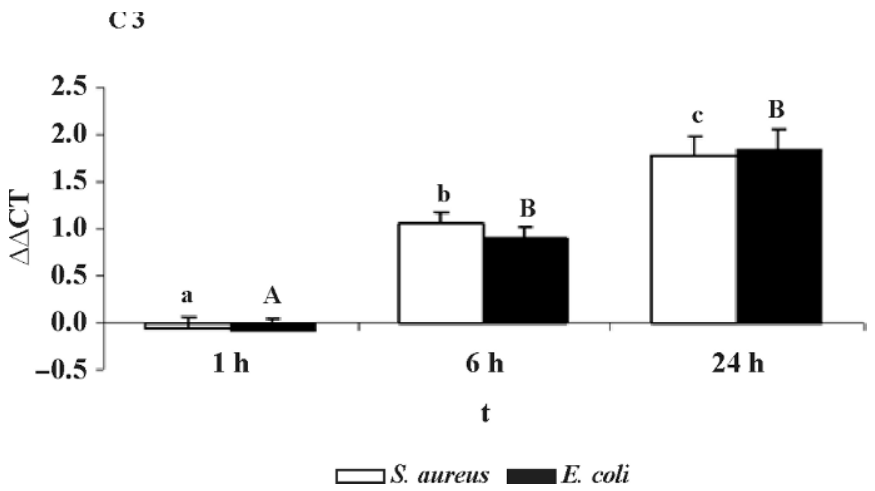

Figure 6. Complement system: mRNA expression $(\Delta \Delta \mathrm{CT})$ of complement factor 3 of 28 cows after treatment with Escherichia coli and Staphylococcus aureus for 1,6 , and $24 \mathrm{~h}(\mathrm{t})$. Data are presented as means \pm SEM. ${ }^{\text {a-c }}$ Means without common letters within the $S$. aureustreated group differ significantly at the measured time points $(P<$ 0.05). ${ }^{\mathrm{A}, \mathrm{B}}$ Means without common letters within the $E$. coli-treated group differ significantly at the measured time points $(P<0.05)$.

gland because this method enables us to investigate a single cell type separately. Of course, in vitro studies can only give an extract of physiological mechanisms happening in a living organism, and it is known that a higher passage number could lead to a loss of characteristic nature of cultured cells (Chennazhy and Krishnan, 2005). Our model diminished this disadvantage by working in the third passage consequently.

Recognition of invading pathogens is the first deciding step in initiating immune defense. The TLR have a key function in pathogen recognition and early immune response (Aderem and Ulevitch, 2000). Strandberg et al. (2005) showed the expression of TLR2 and TLR4 by bMEC and a stimulation of the Toll-like receptor pathway by LPS and lipoteichoic acid. The TLR2 is activated mostly by peptidoglycans and lipoteichoic acids that are components of the cell wall of grampositive bacteria (Takeuchi et al., 1999; Takeda et al., 2003). In our study, we showed a similar increase of TLR2 mRNA expression after $1 \mathrm{~h}$ both in $E$. coli- and $S$. aureus-treated cells. After $24 \mathrm{~h}$ the expression declined in both groups, whereas the TLR2 mRNA level in $S$. aureus-affected epithelial cells was significantly lower than in E. coli-treated cells. Although most studies describe TLR2 as a primary receptor for gram-positive bacteria, it is well known that it is responsive to gram-negatives also (Takeuchi et al., 1999). For our study we used heat-inactivated bacteria that could not divide anymore but contain the typical virulence factors of the pathogens as far as possible, and so we could regard the reaction of bMEC to gram-positives and gram-negatives and not only to certain cell wall components that are often used in vitro experiments. Comparable results were obtained by Goldammer et al. (2004) 
who found an elevation of TLR2 mRNA expression induced both by $S$. aureus and in a lower amount by $E$. coli in mammary epithelial cells isolated from naturally infected udders. These data confirming our results indicate an activation of TLR2 by gram-negatives and gram-positives, whereas the unexpected strong activation by $E$. coli in our experiment could be related to the dose or properties of heat-inactivated bacteria used for treatment. The TLR4 recognizes gram-negative microorganisms, thereby LPS, which contributes to their cell membrane, acts as a ligand (Takeuchi et al., 1999). Our measurements approve the observations that TLR4 is activated only by gram-negative bacteria because no changes in expression could be detected in S. aureustreated mammary epithelial cells. In principle, mRNA expression of TLR2 and TLR4 was higher in cells affected with $E$. coli than with $S$. aureus, which could be a sign of better pathogen recognition of gram-negative bacteria and of a more effective activation of the immune response resulting in a severe but not chronic form of mastitis. Yang et al. (2008), however, recently found similar signal intensities of TLR2 and TLR4 recognizing both $S$. aureus and $E$. coli. Although the authors suggest a lack of $\mathrm{NF} \kappa \mathrm{B}$ activation is responsible for impaired immune response induced by $S$. aureus, quantitative differences in TLR induction could be a further explanation for a diminished activation of immune defense by this pathogen.

Signal transduction connects pathogen recognition and cytokine expression. A key molecule in this mechanism is $\mathrm{NF} \kappa \mathrm{B}$, bonded to an inhibitory protein in the cytoplasm. $\mathrm{NF} \kappa \mathrm{B}$ as a proliferation transcriptional regulator is mostly a heterodimer consisting of RelA and p50 mediating expression of many factors involved in early immune defense (Pahl, 1999). Our experiment demonstrates a similar upregulation of RelA mRNA expression in both treatments after $1 \mathrm{~h}$. Interestingly, expression stayed on this high level after $6 \mathrm{~h}$ in $E$. coli-treated cells, whereas a significant decrease was observed in $S$. aureus affected bMEC. These differences after $6 \mathrm{~h}$ reflect expression profile of TLR4 and could be considered as a result of a lasting stimulation effect of gram-negatives on TLR4 activity. An upregulation of RelA mRNA expression and a nuclear translocation of p50 could be shown in bMEC by Strandberg et al. (2005) after stimulation with LPS indicating the involvement of $\mathrm{NF} \kappa \mathrm{B}$ pathway in signaling transduction in mastitis.

For inducing a systemic reaction and for the recruitment of neutrophils into the udder, several cytokines are responsible. Tumor necrosis factor alpha and IL$1 \beta$, both target genes of $\mathrm{NF} \kappa \mathrm{B}$, are known to induce acute phase reaction in the organism conducted with fever and production of acute phase proteins (Dinarello,
1996; Pahl, 1999). Furthermore, they act locally by activation of expression of adhesion molecules for recruiting neutrophils from the blood into the mammary gland (Wyble et al., 1997). For both factors our measurements show a very strong increase of expression after $1 \mathrm{~h}$, whereas after 6 and $24 \mathrm{~h} \mathrm{E}$. coli induced a significantly higher mRNA level than S. aureus. Most interestingly, after only $1 \mathrm{~h}$ of treatment, $S$. aureus induced a significantly higher expression of both cytokines than $E$. coli. Several studies showed an early elevated level of TNF $\alpha$ and IL-1 $\beta$ mRNA expression in bMEC in vitro and a generally lower reaction of $S$. aureus-treated cells agreeing with our results (Strandberg et al., 2005; Lahouassa et al., 2007). A $S$. aureus-induced protein synthesis of these factors could only be detected in in vitro challenges but not in mastitis milk (Lahouassa et al., 2007). The low amount of these 2 important proinflammatory cytokines on mRNA level could result in a lower amount of protein in milk that is not detectable by ELISA. This could contribute to the chronic course of $S$. aureus mastitis during which cow's general condition is mostly not disturbed. Systemic symptoms as fever, apathy, or anorexia are considered to result from absorption of especially TNF $\alpha$ into circulation what was determined in an in vivo challenge by Hoeben et al. (2000).

The IL-6 is a further cytokine associated with mastitis mediating haematopoiesis, immune regulation, and the acute phase response. Its production by bMEC could be demonstrated (Okada et al., 1997). In vivo, Hagiwara et al. (2001) explored concentrations of IL-6 in whey and serum of healthy cows and cows naturally infected with different mastitis pathogens. Highest concentrations of this cytokine could be found in whey of $E$. coli infected mammary glands of cows with strongest clinical symptoms. Our expression profile of IL-6, according to these observations, shows a similar pattern like IL$1 \beta$ and TNF $\alpha$ with highest levels in $E$. coli-treated cells, whereas after $24 \mathrm{~h}$ no differences between $E$. coli and $S$. aureus could be observed. This could be evidence for an early influence of this cytokine to the course of mastitis.

Fast recruitment of leukocytes into the mammary gland is essential for the elimination of invading pathogens. The chemokine IL-8 has been shown to participate in mastitis in several in vitro and in vivo challenges (Boudjellab et al., 2000; Persson Waller et al., 2003; Wellnitz and Kerr, 2004; Strandberg et al., 2005). In our study $S$. aureus induced a lower mRNA expression of IL-8 than $E$. coli. This presents most likely the IL-8 protein expression of mammary epithelial cells (Wellnitz and Kerr, 2004) and is according to an in vivo experiment of Bannerman et al. (2004) who found an elevation of IL-8 and an elevation of somatic cells associ- 
ated in milk of animals infected with $E$. coli and no detectable IL-8 and a lower number of somatic cells after $S$. aureus infection. The second chemokine we measured was RANTES. To our knowledge its role in mastitis is not clear today, but it has been isolated in human milk cells and an in vitro experiment showed an elevated mRNA expression by bMEC after stimulation with LPS (Srivastava et al., 1996; Pareek et al., 2005). Again E. coli-treated cells showed an elevated level of mRNA expression, but in contrast to IL-8 RANTES was still expressed at a significantly higher level in E. colistimulated cells after $24 \mathrm{~h}$ than in S. aureus-treated cells. This indicates a later role of RANTES in chemotaxis, important not for initiation but for maintenance of inflammation. Notable is the fact that after $1 \mathrm{~h}$ both chemokines were significantly higher expressed in $S$. aureus-treated cells than in $E$. coli-affected bMEC.

The complement system, part of the innate immune system, is involved in numerous host defense activities such as opsonization and lysis of microorganisms or recruitment of phagocytes to site of infection (Frank and Fries, 1991). Most factors are synthesized in the liver, but for C3 a local synthesis in the mammary gland is suggested (Rainard, 2003). The C3 is a key molecule in the complement cascade activated both by the classical and the alternative pathway. Its resulting cleavage products are involved in chemotaxis and opsonization. In our experiment $S$. aureus and $E$. coli induced an increase of C3 mRNA-expression in mammary epithelial cells, supporting the assumption of a local synthesis. No pathogen-dependent differences could be found. In an in vivo experiment Riollet et al. (2000) measured different concentrations of a further protein of the complement cascade, C5a, after intramammary infections with $E$. coli and $S$. aureus. This finding could indicate a deviating production of the origin molecule C5 in the liver as a result of pathogen-related concentrations of the acute phase inducing cytokines what was indicated in in vitro challenges (Perissutti and Tedesco, 1994).

Lactoferrin, an iron-binding protein, synthesized by epithelial cells in the mammary gland, has a very broad spectrum of functions in immune defense, and in the last few years its antibacterial and antiinflammatory properties are a focus of interest for searching new pharmaceutical products (Kutila et al., 2004; Legrand et al., 2004; Orsi, 2004; Ward et al., 2005; Lacasse et al., 2007). Whereas lactoferrin concentration in normal bovine milk is very low, there is an evident increase during mastitis (Kawai et al., 1999; Hagiwara et al., 2003) and Kawai et al. (1999) found a higher lactoferrin concentration in mastitis milk from cows infected with $S$. aureus than with $E$. coli. In our experiment, as far as we know the first one comparing the effect of grampositives and gram-negatives on lactoferrin expression of mammary epithelial cells directly, lactoferrin was the only tested factor showing the highest mRNA expression level in S. aureus affected cells. Epithelial cells in the mammary gland are known to synthesize lactoferrin, and Wellnitz and Kerr (2004) showed an inducible mRNA and protein expression of cryopreserved bMEC treated either with living S. aureus or LPS. Although there are studies documenting a stronger in vitro effect against $E$. coli because of its iron-binding properties and interactions with the cell membrane of $E$. coli, the mechanisms by which lactoferrin inhibits microorganisms are not completely understood until today (Lee et al., 2004; van der Kraan et al., 2005; Ward et al., 2005). One approach concerning predominantly the immunomodulatory characteristics of lactoferrin could be the findings of Berlutti et al. (2006) suggesting that lactoferrin downregulates proinflammatory cytokines expressed by epithelial cells after stimulation with $E$. coli. This complies with our results that showed a significantly higher regulation of lactoferrin in $E$. colitreated cells than in $S$. aureus exposed cells after $1 \mathrm{~h}$ mirroring a significantly lower mRNA level of TNF $\alpha$, IL-1 $\beta$, IL-6, and IL-8 in the $E$. coli treatment. Vice versa the higher level of lactoferrin expression in $S$. aureus treated cells after 6 and $24 \mathrm{~h}$ reflects the lower level of the cytokines mentioned before in this group compared with $E$. coli-exposed cells. The molecular mechanisms of lactoferrin regulation are still under investigation, but its increase in mastitis milk indicates that there is a pathogen-dependent relation. Some authors presume an activation of lactoferrin gene expression dependent on $\mathrm{NF} \kappa \mathrm{B}$ but the signaling pathways are still unidentified (Zheng et al., 2005; Curran et al., 2006). The converse expression pattern of lactoferrin and the proinflammatory cytokines and chemokines confirming the examinations of others that lactoferrin has an antiinflammatory effect could be one of the mechanisms determining the clinical course of mastitis. Further investigations concerning lactoferrin activation are needed to place this protein in the complex network of cytokines and to use its immunomodulatory impact successfully for therapeutical intervention in $E$. coli caused acute mastitis.

\section{CONCLUSIONS}

Our experiment distinguishes itself from others by a standardized cell culture model based on 28 firstlactation healthy cows. The results obtained provide a reliable mRNA expression profile of mammary epithelial cells reacting to different mastitis pathogens, thus confirming the role of these cells in the immune defense of the mammary gland. On the one hand the expression pattern of TLR indicates a more effective recognition 
of gram-negative than of gram-positive bacteria resulting in higher expression of cytokines and chemokines by cells treated with $E$. coli than with $S$. aureus. On the other hand the regulation of lactoferrin in vitro indicates an immunomodulatory influence of this molecule to the expression of proinflammatory cytokines and chemokines in mastitis that remains to be clarified in further experiments.

\section{ACKNOWLEDGMENTS}

This study was financially supported within the FUGATO project MAS.net by the Froederverein Biotechnologie-Forschung (FBF) and the Federal Ministry of Education and Research (BMBF). The authors thank the laboratory staffs of FBN and of the Veterinary Physiology Bern for their hospitality and assistance.

\section{REFERENCES}

Aderem, A., and R. J. Ulevitch. 2000. Toll-like receptors in the induction of the innate immune response. Nature 406:782-787.

Bannerman, D. D., M. J. Paape, J. W. Lee, X. Zhao, J. C. Hope, and P. Rainard. 2004. Escherichia coli and Staphylococcus aureus elicit differential innate immune responses following intramammary infection. Clin. Diagn. Lab. Immunol. 11:463-472.

Barkema, H. W., Y. H. Schukken, and R. N. Zadoks. 2006. The role of cow, pathogen, and treatment regimen in the therapeutic success of bovine Staphylococcus aureus mastitis. J. Dairy Sci. 89:1877-1895.

Berlutti, F., S. Schippa, C. Morea, S. Sarli, B. Perfetto, G. Donnarumma, and P. Valenti. 2006. Lactoferrin downregulates pro-inflammatory cytokines upexpressed in intestinal epithelial cells infected with invasive or noninvasive Escherichia coli strains. Biochem. Cell Biol. 84:351-357.

Boudjellab, N., H. S. Chan-Tang, and X. Zhao. 2000. Bovine interleukin-1 expression by cultured mammary epithelial cells (MAC-T) and its involvement in the release of MAC-T derived interleukin8. Comp. Biochem. Physiol. A 127:191-199.

Bramley, A. J., A. H. Patel, M. O'Reilly, R. Foster, and T. J. Foster. 1989. Roles of alpha-toxin and beta-toxin in virulence of Staphylococcus aureus for the mouse mammary gland. Infect. Immun. 57:2489-2494

Burvenich, C., V. van Merris, J. Mehrzad, A. Diez-Fraile, and L. Duchateau. 2003. Severity of E. coli mastitis is mainly determined by cow factors. Vet. Res. 34:521-564.

Chennazhy, K. P., and L. K. Krishnan. 2005. Effect of passage number and matrix characteristics on differentiation of endothelial cells cultured for tissue engineering. Biomaterials 26:5658-5667.

Curran, C. S., K. P. Demick, and J. M. Mansfield. 2006. Lactoferrin activates macrophages via TLR4-dependent and -independent signaling pathways. Cell. Immunol. 242:23-30.

Dinarello, C. A. 1996. Cytokines as mediators in the pathogenesis of septic shock. Curr. Top. Microbiol. Immunol. 216:133-165.

Frank, M. M., and L. F. Fries. 1991. The role of complement in inflammation and phagocytosis. Immunol. Today 12:322-326.

Goldammer, T., H. Zerbe, A. Molenaar, H. J. Schuberth, R. M. Brunner, S. R. Kata, and H. M. Seyfert. 2004. Mastitis increases mammary mRNA abundance of beta-defensin 5, Toll-like-receptor 2 (TLR2), and TLR4 but not TLR9 in cattle. Clin. Diagn. Lab. Immunol. 11:174-185.

Hagiwara, S., K. Kawai, A. Anri, and H. Nagahata. 2003. Lactoferrin concentrations in milk from normal and subclinical mastitic cows. J. Vet. Med. Sci. 65:319-323.

Hagiwara, K., H. Yamanaka, K. Hisaeda, S. Taharaguchi, R. Kirisawa, and H. Iwai. 2001. Concentrations of IL-6 in serum and whey from healthy and mastitic cows. Vet. Res. Commun. 25:99-108

Hoeben, D., C. Burvenich, E. Trevisi, G. Bertoni, J. Hamann, R. M. Bruckmaier, and J. W. Blum. 2000. Role of endotoxin and TNFalpha in the pathogenesis of experimentally induced coliform mastitis in periparturient cows. J. Dairy Res. 67:503-514.

Hogan, J., and K. L. Smith. 2003. Coliform mastitis. Vet. Res. 34:507-519.

Kawai, K., S. Hagiwara, A. Anri, and H. Nagahata. 1999. Lactoferrin concentration in milk of bovine clinical mastitis. Vet. Res. Commun. 23:391-398.

Korhonen, H., P. Marnila, and H. S. Gill. 2000. Milk immunoglobulins and complement factors. Br. J. Nutr. 84(Suppl. 1):75-80.

Kutila, T., L. Suojala, T. Lehtolainen, H. Saloniemi, L. Kaartinen, M. Tahti, K. Seppala, and S. Pyorala. 2004. The efficacy of bovine lactoferrin in the treatment of cows with experimentally induced Escherichia coli mastitis. J. Vet. Pharmacol. Ther. 27:197-202.

Lacasse, P., K. Lauzon, M. S. Diarra, and D. Petitclerc. 2007. Utilization of lactoferrin to fight antibiotic resistant mammary gland pathogens. J. Anim. Sci.

Lahouassa, H., E. Moussay, P. Rainard, and C. Riollet. 2007. Differential cytokine and chemokine responses of bovine mammary epithelial cells to Staphylococcus aureus and Escherichia coli. Cytokine 38:12-21.

Lee, N. Y., K. Kawai, I. Nakamura, T. Tanaka, H. Kumura, and K. Shimazaki. 2004. Susceptibilities against bovine lactoferrin with microorganisms isolated from mastitic milk. J. Vet. Med. Sci. 66:1267-1269.

Legrand, D., E. Elass, A. Pierce, and J. Mazurier. 2004. Lactoferrin and host defence: An overview of its immuno-modulating and anti-inflammatory properties. Biometals 17:225-229.

Liang, Y., Y. Zhou, and P. Shen. 2004. NF-kappaB and its regulation on the immune system. Cell. Mol. Immunol. 1:343-350.

Livak, K. J., and T. D. Schmittgen. 2001. Analysis of relative gene expression data using real-time quantitative PCR and the 2(Delta Delta C(T)). Methods 25:402-408.

McManaman, J. L., and M. C. Neville. 2003. Mammary physiology and milk secretion. Adv. Drug Deliv. Rev. 55:629-641.

Menzies, M., and A. Ingham. 2006. Identification and expression of Toll-like receptors 1-10 in selected bovine and ovine tissues. Vet. Immunol. Immunopathol. 109:23-30.

Okada, H., T. Ito, H. Ohtsuka, R. Kirisawa, H. Iwai, K. Yamashita, T. Yoshino, and T. J. Rosol. 1997. Detection of interleukin-1 and interleukin- 6 on cryopreserved bovine mammary epithelial cells in vitro. J. Vet. Med. Sci. 59:503-507.

Orsi, N. 2004. The antimicrobial activity of lactoferrin: Current status and perspectives. Biometals 17:189-196.

Pahl, H. L. 1999. Activators and target genes of Rel/NF-kappaB transcription factors. Oncogene 18:6853-6866.

Pandey, S., and D. K. Agrawal. 2006. Immunobiology of Toll-like receptors: Emerging trends. Immunol. Cell Biol. 84:333-341.

Pareek, R., O. Wellnitz, R. van Dorp, J. Burton, and D. Kerr. 2005. Immunorelevant gene expression in LPS-challenged bovine mammary epithelial cells. J. Appl. Genet. 46:171-177.

Perissutti, S., and F. Tedesco. 1994. Effect of cytokines on the secretion of the fifth and eighth complement components by HepG2 cells. Int. J. Clin. Lab. Res. 24:45-48.

Persson Waller, K., I. G. Colditz, S. Lun, and K. Ostensson. 2003. Cytokines in mammary lymph and milk during endotoxin-induced bovine mastitis. Res. Vet. Sci. 74:31-36.

Pfaffl, M. W., S. L. Wittmann, H. H. Meyer, and R. M. Bruckmaier. 2003. Gene expression of immunologically important factors in blood cells, milk cells, and mammary tissue of cows. J. Dairy Sci. 86:538-545.

Rainard, P. 2003. The complement in milk and defense of the bovine mammary gland against infections. Vet. Res. 34:647-670.

Rainard, P., and C. Riollet. 2006. Innate immunity of the bovine mammary gland. Vet. Res. 37:369-400.

Riollet, C., P. Rainard, and B. Poutrel. 2000. Differential induction of complement fragment C5a and inflammatory cytokines during intramammary infections with Escherichia coli and Staphylococcus aureus. Clin. Diagn. Lab. Immunol. 7:161-167. 
Schmitz, S., M. W. Pfaffl, H. H. Meyer, and R. M. Bruckmaier. 2004. Short-term changes of mRNA expression of various inflammatory factors and milk proteins in mammary tissue during LPS-induced mastitis. Domest. Anim. Endocrinol. 26:111-126.

Seegers, H., C. Fourichon, and F. Beaudeau. 2003. Production effects related to mastitis and mastitis economics in dairy cattle herds. Vet. Res. 34:475-491.

Srivastava, M. D., A. Srivastava, B. Brouhard, R. Saneto, S. GrohWargo, and J. Kubit. 1996. Cytokines in human milk. Res. Commun. Mol. Pathol. Pharmacol. 93:263-287.

Strandberg, Y., C. Gray, T. Vuocolo, L. Donaldson, M. Broadway, and R. Tellam. 2005. Lipopolysaccharide and lipoteichoic acid induce different innate immune responses in bovine mammary epithelial cells. Cytokine 31:72-86.

Sutra, L., and B. Poutrel. 1994. Virulence factors involved in the pathogenesis of bovine intramammary infections due to Staphylococcus aureus. J. Med. Microbiol. 40:79-89.

Takeda, K., T. Kaisho, and S. Akira. 2003. Toll-like receptors. Annu. Rev. Immunol. 21:335-376.

Takeuchi, O., K. Hoshino, T. Kawai, H. Sanjo, H. Takada, T. Ogawa, K. Takeda, and S. Akira. 1999. Differential roles of TLR2 and TLR4 in recognition of gram-negative and gram-positive bacterial cell wall components. Immunity 11:443-451.

Teng, C. T. 1999. Regulation of lactoferrin gene expression by estrogen and epidermal growth factor: Molecular mechanism. Cell Biochem. Biophys. 31:49-64.
Teng, C. T. 2002. Lactoferrin gene expression and regulation: An overview. Biochem. Cell Biol. 80:7-16.

van der Kraan, M. I., J. van Marle, K. Nazmi, J. Groenink, W. van 't Hof, E. C. Veerman, J. G. Bolscher, and A. V. Nieuw Amerongen. 2005. Ultrastructural effects of antimicrobial peptides from bovine lactoferrin on the membranes of Candida albicans and Escherichia coli. Peptides 26:1537-1542.

Ward, P. P., E. Paz, and O. M. Conneely. 2005. Multifunctional roles of lactoferrin: A critical overview. Cell. Mol. Life Sci. 62:2540-2548.

Wellnitz, O., and D. E. Kerr. 2004. Cryopreserved bovine mammary cells to model epithelial response to infection. Vet. Immunol. Immunopathol. 101:191-202.

Wyble, C. W., K. L. Hynes, J. Kuchibhotla, B. C. Marcus, D. Hallahan, and B. L. Gewertz. 1997. TNF-alpha and IL-1 upregulate membrane-bound and soluble E-selectin through a common pathway. J. Surg. Res. 73:107-112.

Yang, W., H. Zerbe, W. Petzl, R. M. Brunner, J. Günther, C. Draing, S. von Aulock, H. J. Schuberth, and H. M. Seyfert. 2008. Bovine TLR2 and TLR4 properly transduce signals from Staphylococcus aureus and $E$. coli, but $S$. aureus fails to both activate NF-kappaB in mammary epithelial cells and to quickly induce TNFalpha and interleukin-8 (CXCL8) expression in the udder. Mol. Immunol. 45:1385-1397.

Zheng, J., J. L. Ather, T. S. Sonstegard, and D. E. Kerr. 2005. Characterization of the infection-responsive bovine lactoferrin promoter. Gene 353:107-117. 